\title{
Acrodermatitis Continua of Hallopeau Evolving into Generalized Pustular Psoriasis Following COVID-19: A Case Report of a Successful Treatment with Infliximab in Combination with Acitretin
}

\author{
Dominik Samotij (D' \\ Ewelina Gawron' \\ Justyna Szczęch' \\ Elżbieta Ostańska (iD) ${ }^{2}$ \\ Adam Reich' \\ 'Department of Dermatology, Institute of \\ Medical Sciences, Medical College of \\ Rzeszow University, Rzeszów, Poland; \\ ${ }^{2}$ Department of Pathology, Institute of \\ Medical Sciences, Medical College of \\ Rzeszow University, Rzeszów, Poland
}

Correspondence: Adam Reich Department of Dermatology, Institute of Medical Sciences, Medical College of

Rzeszow University, ul. Fryderyka

Szopena 2, Rzeszów, 35-055, Poland

Tel +48 605076722

Fax +48178666294

Email adamandrzejreich@gmail.com

\begin{abstract}
The global pandemic of coronavirus disease 2019 (COVID-19) caused by the novel severe acute respiratory syndrome coronavirus 2 (SARS-CoV-2) is emerging. Various cutaneous manifestations have been observed in patients with SARS-CoV-2 infection, yet exacerbations of psoriasis have been reported sporadically. Acrodermatitis continua of Hallopeau $(\mathrm{ACH})$ is an uncommon, sterile pustular dermatosis involving one or more digits. In some rare cases, $\mathrm{ACH}$ may evolve into generalized pustular psoriasis (GPP), which is a severe, and potentially life-threatening, form of psoriasis that manifests itself with widespread eruptions of pustules. We describe the first case of a patient in whom ACH abruptly progressed into GPP during COVID-19. A combination of infliximab and acitretin was used allowing swift clinical improvement.
\end{abstract}

Keywords: psoriasis, pustular psoriasis, biologics, biologic therapy, SARS-CoV-2, coronavirus

\section{Introduction}

The first human case of infection by the novel coronavirus, severe acute respiratory syndrome coronavirus 2 (SARS-CoV-2), was reported in Wuhan, China, in late November 2019. In December 2019, several patients have been hospitalized for acute pneumonia of unknown origin. ${ }^{1}$ Shortly afterwards, SARS-CoV-2 has been found in the lower respiratory tract of hospitalized patients, and the World Health Organization (WHO) recognized the disease as Coronavirus Disease 2019 (COVID-19) on January 12, 2020. On March 11, 2020 the WHO declared the COVID-19 outbreak as pandemic. ${ }^{2}$ The most common symptoms in COVID-19 are fever, fatigue, dry cough, and dyspnoea succeeded by other symptoms, such as headache, nasal congestion, sore throat, myalgia, arthralgia, and a variety of other extrapulmonary symptoms either as the initial presentation or as sequelae. ${ }^{1,3,4}$ Initially, no skin involvement during SARS-CoV-2 infection was observed, but more recently, numerous heterogeneous cutaneous manifestations have been reported. Incidence of the skin lesions associated with SARS-CoV-2 infection varies according to the case series, ranging from $0.2 \%$ to $20.5 \%{ }^{5}$ Secondary skin 
reactions to different treatments for COVID-19 are also possible, as well as worsening of preexisting dermatological conditions.

In this article, we report the first case of a patient with acrodermatitis continua of Hallopeau (ACH) that progressed into generalized pustular psoriasis (GPP) during COVID-19.

\section{Case Report}

A 72-year-old woman with a 9-year history of a hard-to-treat $\mathrm{ACH}$ presented in our department in November 2020 with a generalized pustular eruption overlying erythematous plaques and patches of subacute onset that had appeared 2 weeks earlier. Skin lesions were accompanied by general symptoms such as high-grade fever (up to $39.2^{\circ} \mathrm{C}$ ) and gradually increasing malaise. Four weeks before she had experienced persistent dry cough, overall fatigue, myalgia, muscle weakness, headache and fever with accompanying dysgeusia and anosmia lasting several days. At that time, reverse transcriptase polymerase chain reaction (RT-PCR) by nasopharyngeal swab testing was performed yielding positive result for SARS-CoV-2 and confirming COVID-19. Interestingly, the patient noticed that almost immediately after the first symptoms of COVID-19 had appeared, pustular lesions in the course of $\mathrm{ACH}$, which at the time were present but confined to the digits and toes, started to eruptively spread to the trunk and extremities. Notably, although the patient was refractory to or intolerant of previous multiple systemic treatment modalities including methotrexate, adalimumab, acitretin, and cyclosporine A, she never showed psoriatic lesions in locations other than acral aspects of the hands and feet. With respect to the potential drug causality, therapeutic regimen for COVID-19 included a 5-day course of azithromycin and low doses of oral paracetamol. The patient had a history of paracetamol intake in the past which was never associated with exacerbation of her $\mathrm{ACH}$. Of note, the last medication the patient was on prior to the GPP onset was cyclosporine A. It was however tapered gradually and stopped 6 weeks before the here described flare; therefore, it is not likely that cyclosporine A withdrawal contributed to $\mathrm{ACH}$ evolving into GPP. No other potentially precipitating events were identified by the patient.

On admission, the patient presented with scattered pustules on a scaly, erythematous base predominantly on the lower back and upper thighs. Several of the lesions had coalesced into crusted erythematous plaques covered with lakes of pus over extensor surfaces of elbows (Figure 1). Examination of the scalp showed confluent erythematous

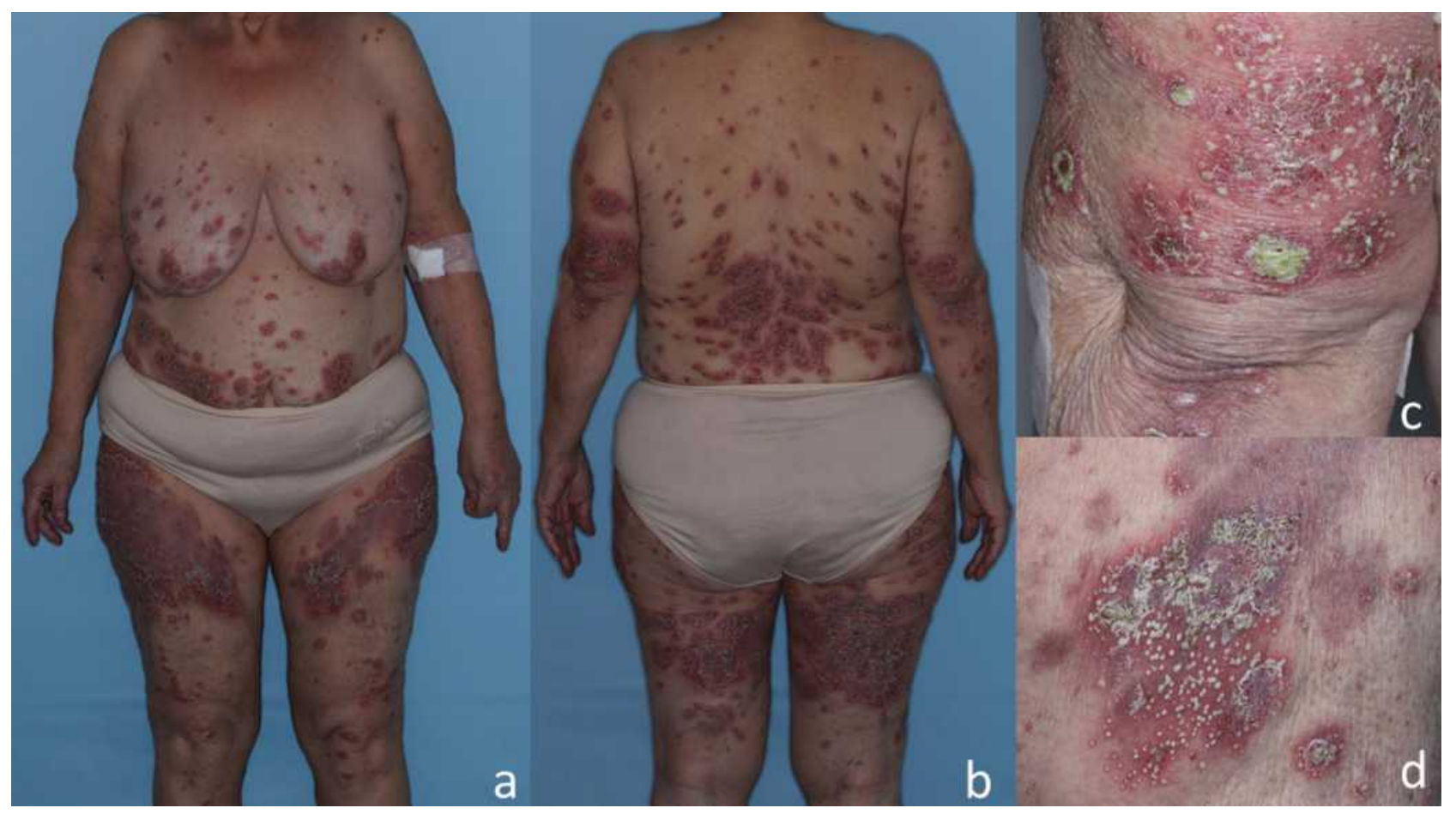

Figure I Clinical presentation of the patient on admission. Scattered pustules over diffuse, symmetrical erythematous patches and plaques that arise predominantly on the lower back and upper thighs (A and B). The lesions coalesced into crusted erythematous plaques covered with larger pustules and lakes of pus over extensor surface of the left elbow (C) and inner upper left thigh (D). 
plaques with silvery scaling. Onycholysis of the fingers and toes was present as a result of severe subungual pustulation. No oral or ocular involvement was noted. The initial severity of the disease was classified as moderate ( 6 out of 10 points) using the classification proposed by Umezawa et al. ${ }^{6}$

Initial blood test performed during admission revealed mild neutrophilic leukocytosis with white blood cell count of $14,460 / \mu \mathrm{L}$ (reference range, $4,000-10,000 / \mu \mathrm{L}$ ), neutrophil count, $10,240 / \mu \mathrm{L}$ (reference range, $1,800-7,700 / \mu \mathrm{L}$ ), high C-reactive protein of $18.1 \mathrm{mg} / \mathrm{dL}$ (reference range, $<1.0 \mathrm{mg}$ / $\mathrm{dL}$ ), and elevated erythrocyte sedimentation rate, $28 \mathrm{~mm} / \mathrm{h}$ (reference range $0-20 \mathrm{~mm} / \mathrm{h}$ ); elevated serum aspartate aminotransferase of $78 \mathrm{U} / \mathrm{L}$ (reference range, 14-36 U/L) and serum alanine aminotransferase of $98 \mathrm{U} / \mathrm{L}$ (reference range, $<35 \mathrm{U} / \mathrm{L}$ ) were also noted. Histopathological findings of lesional skin biopsy specimen were compatible with GPP and revealed intraepidermal spongiform pustule consisting of accumulated neutrophils in an acanthotic, hyperkeratotic and parakeratotic epidermis. The dermis showed a sparse perivascular mixed inflammatory infiltrate (Figure 2).

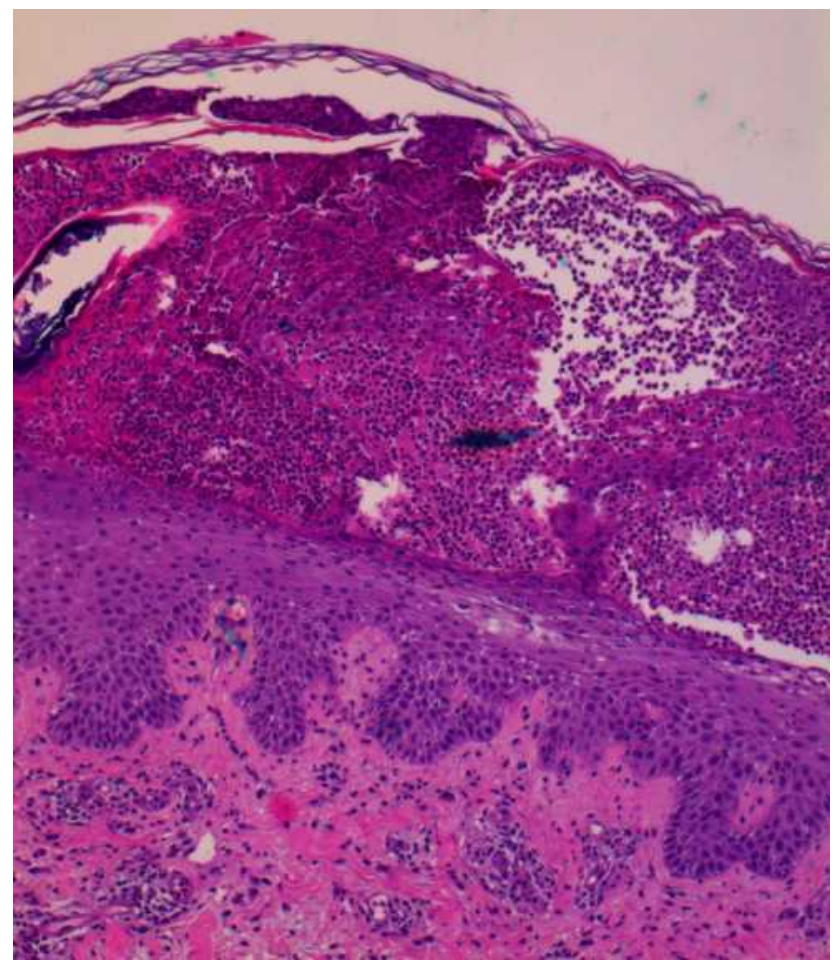

Figure 2 Histopathological findings of lesional skin biopsy showing intraepidermal spongiform pustule consisting of accumulated neutrophils in an acanthotic, hyperkeratotic and parakeratotic epidermis. The dermis showed a sparse perivascular mixed inflammatory infiltrate ( $x 100$, hematoxylin and eosin [H\&E]).
The patient was initially commenced on acitretin at a dose of $50 \mathrm{mg}$ daily combined with a short course of intravenous hydrocortisone, but the clinical response assessed after 7 days of treatment was unsatisfactory as new crops of pustules continued to appear. Based on the current recommendations and personal experience, infliximab was added to the regime at a dose of $5 \mathrm{mg} / \mathrm{kg}$ body weight intravenously after a negative swab result for SARS-CoV-2 had been obtained. ${ }^{7}$ The plaques and pustules, as well as the laboratory parameters, dramatically improved in the ensuing 72 hours; the GPP score improved from 6 to 2 points, which corresponded to mild severity as per the aforementioned classification. ${ }^{6}$

The patient was discharged from the hospital on acitretin $35 \mathrm{mg}$ daily $(0.5 \mathrm{mg} / \mathrm{kg}$ daily based on the actual body weight), with the next infusion scheduled 2 weeks after the initial one. Photographs of the patient taken on the day of the second infusion of infliximab are shown in Figure 3.

\section{Review of the Literature and Discussion}

GPP, first described by von Zumbusch in 1910, is an infrequent and severe inflammatory dermatosis characterized by the appearance of sudden, widespread eruption of erythematous plaques covered with superficial coalescing sterile pustules and multisystem symptoms. ${ }^{8,9}$

$\mathrm{ACH}$ is a rare, chronic and highly recalcitrant localized pustular eruption involving the digits and nails. ${ }^{9-11}$ There has long been debated whether $\mathrm{ACH}$ is an independent disease or a localized form of pustular psoriasis (PP). ${ }^{13}$ $\mathrm{ACH}$ may rarely evolve into GPP, especially in elderly patients. $^{14,15}$ Case reports describing $\mathrm{ACH}$ transitioning into GPP, as well as the presence of aberrant interleukin36-receptor antagonist (IL-36Ra) in both diseases, may serve as a support for $\mathrm{ACH}$ probably not being a distinct entity, but a localized form of GPP. ${ }^{13}$ Co-occurrence of both forms of psoriasis has also been reported. ${ }^{8,14-16}$ GPP and $\mathrm{ACH}$ are currently recognized as subtypes of PP, alongside with palmoplantar pustulosis. ${ }^{9}$

Infectious diseases have long been considered as one of the triggers for autoimmune and autoinflammatory diseases, mainly via molecular mimicry. ${ }^{17}$ Viral infections have been extensively identified as potential etiological factors in GPP, including cytomegalovirus, Epstein-Barr virus, varicella zoster virus, and more recently Zika virus. $^{18-22}$ Whether novel $\beta$-coronavirus SARS-CoV-2 infection can directly cause a worsening of preexisting 


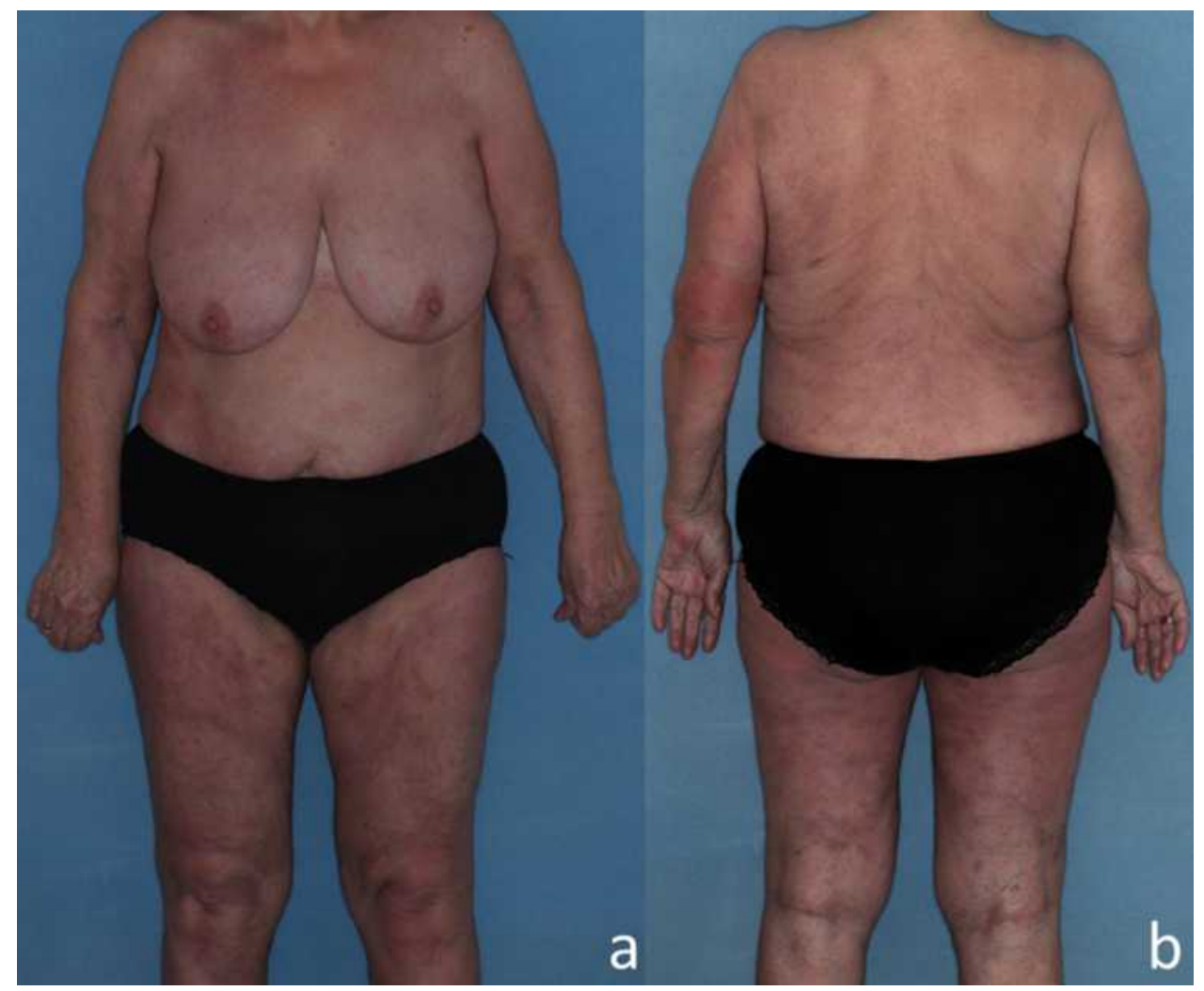

Figure 3 Clinical presentation of the patient 21 days after the initial photographs were taken. Dramatic improvement of the lesions 2 weeks after the first infusion of infliximab and 3-week treatment with acitretin ( $\mathbf{A}$ and $\mathbf{B})$.

chronic inflammatory diseases such as psoriasis remains to be determined. A possible pathomechanism for viral infection leading to GPP flare is related to stimulation of Tolllike receptor 3 (TLR3) by polyinosinic:polycytidylic acid mimicking viral RNA leading to overproduction of proinflammatory cytokine interleukin-36 gamma (IL-36- $\gamma$ ) and C-X-C motif chemokine ligand 8 (CXCL8) thereby dysregulating innate immune response. ${ }^{23,24}$ It has been shown that several inflammatory cytokines downstream from TLR3, including IL-36, are pathogenic in GPP. ${ }^{25}$

A wide spectrum of cutaneous associations with SARSCoV-2 infection has been described so far, but yet exacerbations of psoriasis have been reported only a handful of times (as of December 2020). ${ }^{26-29}$ To our knowledge, there have been seven cases of psoriasis exacerbation related to COVID-19 and one case of a new-onset GPP in this setting documented to date. The first report involved a patient who developed widespread psoriatic plaques on the fourth day of treatment with oseltamivir and hydroxychloroquine. ${ }^{30}$ It was however uncertain whether the exacerbation of psoriasis was due to underlying SARS-CoV-2 infection or hydroxychloroquine treatment as antimalarials have been extensively reported to worsen the preexisting psoriasis. ${ }^{31}$ Ozaras et al described a case of plaque psoriasis flare-up in a 48-year-old woman in whom COVID-19 was treated with hydroxychloroquine, azithromycin, oseltamivir, and inhaled ipratropium and budesonide. Interestingly, psoriatic lesions in this patient regressed without any specific treatment. Similarly to the previous case, the possibility of hydroxychloroquine being the trigger medication could not have been excluded. ${ }^{32}$ Another case reported a 73-year-old man on maintenance cyclosporine A and methotrexate for psoriasis who had the medications discontinued in the setting of a SARS-CoV-2 infection prompting a psoriasis flare two weeks later followed by improvement once cyclosporine $\mathrm{A}$ was reinitiated. ${ }^{33}$ There is also a case report of a 38 -year-oldman with a history of chronic plaque psoriasis who suffered from guttate psoriasis secondary to COVID-19, which appeared on the sixth day after the onset of fever. ${ }^{34}$ Subsequently, a 45-year-old male was reported with recurrence of severe psoriatic erythroderma and a positive test for SARS-CoV-2, but also Staphylococcus aureus isolated from blood culture samples. Given this patient's discontinuation of cyclosporine A 3 weeks prior, it is safe to assume that SARS- 
CoV-2 was not the only contributing factor to psoriasis exacerbation. ${ }^{35} \mathrm{~A}$ recently published case report of a 62 year-old-woman with a positive family history for psoriasis differed from the aforementioned ones as the described patient developed a new-onset PP two weeks after the resolution of SARS-CoV-2 infection symptoms. ${ }^{36}$ In November 2020, another case of PP exacerbation secondary to COVID-19 was published. The described patient was also treated with hydroxychloroquine, albeit unlike the previously reported cases, she had a history of hydroxychloroquine use without exacerbation of psoriasis; therefore, the authors concluded that SARS-CoV-2 alone might have led to the PP flare-up. ${ }^{37}$ Lastly, the most recent case detailed a 60 -year-old male with a childhood history of psoriasis who developed GPP 26 days after the initial symptoms of COVID-19 had appeared. ${ }^{38}$ Results of the literature review and the presented case are summarized in Table 1. Slightly different, yet very interesting, case was presented by Sbidian et al who collected data on onset or flare of psoriasis within 3 months following the 2009 monovalent $\mathrm{H}_{1} \mathrm{~N}_{1}$ /seasonal vaccinations in France. A patient known to suffer from GPP showed 2 successive severe GPP flares after 2 different vaccine injections, the first flare occurred 6 days after pneumococcal vaccination and the second one was observed 3 days after the 2009 monovalent $\mathrm{H}_{1} \mathrm{~N}_{1}$ vaccine including adjuvant. ${ }^{39}$

\section{Conclusion}

In summary, COVID-19-induced hyperinflammatory state is perhaps more probable explanation of psoriasis exacerbation during the infection than a molecular mimicry, provided that iatrogenic causes are excluded (eg, hydroxychloroquine usage, rapid tapering of corticosteroids). In the light of emerging evidence, COVID-19 may be a new entity that is able to aggravate already existing

Table I Summary of the Current Case and Reported Cases of Psoriasis in the Setting of COVID-I9 Infection

\begin{tabular}{|c|c|c|c|c|c|c|c|c|}
\hline & Study & $\begin{array}{l}\text { Patient } \\
\text { Gender }\end{array}$ & $\begin{array}{l}\text { Patient } \\
\text { Age, } \\
\text { Years }\end{array}$ & $\begin{array}{l}\text { Preexisting } \\
\text { Psoriasis } \\
\text { Phenotype }\end{array}$ & $\begin{array}{l}\text { Psoriasis } \\
\text { Phenotype } \\
\text { After SARS- } \\
\text { CoV-2 } \\
\text { Infection }\end{array}$ & $\begin{array}{l}\text { Treatment of the } \\
\text { Exacerbation of } \\
\text { Psoriasis }\end{array}$ & $\begin{array}{l}\text { Other Factors That Could } \\
\text { Have Potentially } \\
\text { Exacerbated Psoriasis }\end{array}$ & $\begin{array}{l}\text { Reference } \\
\text { Number }\end{array}$ \\
\hline -* & Current study & Female & 72 & $\begin{array}{l}\text { Acrodermatitis } \\
\text { continua of } \\
\text { Hallopeau }\end{array}$ & $\begin{array}{l}\text { Generalized } \\
\text { pustular } \\
\text { psoriasis }\end{array}$ & $\begin{array}{l}\text { Infliximab } 5 \mathrm{mg} / \mathrm{kg} \\
\text { combined with acitretin } \\
35 \mathrm{mg} / \mathrm{d}\end{array}$ & - & $-*$ \\
\hline 1 & Kutlu et al & Female & 71 & Plaque psoriasis & $\begin{array}{l}\text { Plaque } \\
\text { psoriasis }\end{array}$ & Unreported & $\begin{array}{l}\text { Hydroxychloroquine treatment } \\
\text { for COVID-19 }\end{array}$ & [30] \\
\hline 2 & Ozaras et al & Female & 48 & Plaque psoriasis & $\begin{array}{l}\text { Plaque } \\
\text { psoriasis }\end{array}$ & $\begin{array}{l}\text { None, the lesions } \\
\text { resolved spontaneously }\end{array}$ & $\begin{array}{l}\text { Hydroxychloroquine treatment } \\
\text { for COVID-19 }\end{array}$ & [32] \\
\hline 3 & Nasiri et al & Male & 73 & Plaque psoriasis & $\begin{array}{l}\text { Plaque } \\
\text { psoriasis }\end{array}$ & Cyclosporine A $100 \mathrm{mg} / \mathrm{d}$ & $\begin{array}{l}\text { Hydroxychloroquine treatment } \\
\text { for COVID-19 }\end{array}$ & [33] \\
\hline 4 & $\begin{array}{l}\text { Gananandan } \\
\text { et al }\end{array}$ & Male & 38 & Plaque psoriasis & $\begin{array}{l}\text { Guttate } \\
\text { psoriasis }\end{array}$ & $\begin{array}{l}\text { Betamethasone } 0.025 \% \\
\text { cream }\end{array}$ & - & [34] \\
\hline 5 & $\begin{array}{l}\text { Ghalamkarpour } \\
\text { et al }\end{array}$ & Male & 45 & $\begin{array}{l}\text { Psoriatic } \\
\text { erythroderma }\end{array}$ & $\begin{array}{l}\text { Psoriatic } \\
\text { erythroderma }\end{array}$ & $\begin{array}{l}\text { Initially acitretin } 35 \mathrm{mg} / \mathrm{d} \text {, } \\
\text { later cyclosporine } \\
\text { A } 200 \mathrm{mg} / \mathrm{d} \text { combined } \\
\text { with oral prednisolone }\end{array}$ & $\begin{array}{l}\text { Cyclosporine A discontinuation } \\
3 \text { weeks prior to the } \\
\text { exacerbation, Staphylococcus } \\
\text { aureus was isolated from the } \\
\text { blood culture }\end{array}$ & [35] \\
\hline 6 & Mathieu et al & Female & 62 & $\begin{array}{l}\text { Not applicable, } \\
\text { new onset }\end{array}$ & $\begin{array}{l}\text { Pustular } \\
\text { psoriasis }\end{array}$ & Unreported & - & [36] \\
\hline 7 & Shakoei et al & Female & 47 & $\begin{array}{l}\text { Pustular } \\
\text { psoriasis }\end{array}$ & $\begin{array}{l}\text { Pustular } \\
\text { psoriasis }\end{array}$ & Unreported & $\begin{array}{l}\text { Hydroxychloroquine treatment } \\
\text { for COVID-19 }\end{array}$ & [37] \\
\hline 8 & Dadras et al & Male & 60 & Plaque psoriasis & $\begin{array}{l}\text { Generalized } \\
\text { pustular } \\
\text { psoriasis }\end{array}$ & $\begin{array}{l}\text { Acitretin } 25 \mathrm{mg} / \mathrm{d} \\
\text { combined with oral } \\
\text { prednisolone }\end{array}$ & - & [38] \\
\hline
\end{tabular}

Note: *Present case.

Abbreviations: COVID-19, coronavirus disease 2019; SARS-CoV-2, severe acute respiratory syndrome coronavirus 2. 
psoriasis, trigger psoriasis de novo or, as it occurred in the case described herein, modify the phenotype of the disease.

\section{Ethical Considerations}

Written informed consent has been provided by the patient to have the case details and accompanying images published. No institutional approval was required to publish the case details.

\section{Acknowledgments}

The authors would like to sincerely thank our patient for her cooperation.

\section{Disclosure}

No funding was received for this manuscript. The authors declare no conflicts of interest in this work.

\section{References}

1. Rothan HA, Byrareddy SN. The epidemiology and pathogenesis of coronavirus disease (COVID-19) outbreak. J Autoimmun. 2020;109:102433. doi:10.1016/j.jaut.2020.102433

2. Cucinotta D, Vanelli M. WHO declares COVID-19 a pandemic. Acta Biomed. 2020;91(1):157-160. doi:10.23750/abm.v91i1.9397

3. Singhal TA. A review of coronavirus disease-2019 (COVID-19). Indian J Pediatr. 2020;87(4):281-286. doi:10.1007/s12098-02003263-6

4. Abobaker A, Raba AA, Alzwi A. Extrapulmonary and atypical clinical presentations of COVID-19. J Med Virol. 2020;92 (11):2458-2464. doi:10.1002/jmv.26157

5. Fernandez-Nieto D, Ortega-Quijano D, Suarez-Valle A, Jimenez-Cauhe J, Jaen-Olasolo P, Fernandez-Guarino M. Lack of skin manifestations in COVID-19 hospitalized patients during the second epidemic wave in Spain: a possible association with a novel SARS-CoV-2 variant - a cross-sectional study. J Eur Acad Dermatol Venereol. 2020. doi:10.1111/jdv.17051

6. Umezawa Y, Ozawa A, Kawasima T, et al. Therapeutic guidelines for the treatment of generalized pustular psoriasis (GPP) based on a proposed classification of disease severity. Arch Dermatol Res. 2003;295(Suppl 1):S43-54. doi:10.1007/s00403-002-0371-6

7. Robinson A, Van Voorhees AS, Hsu S, et al. Treatment of pustular psoriasis: from the Medical Board of the National Psoriasis Foundation. $J$ Am Acad Dermatol. 2012;67(2):279-288. doi:10.1016/j.jaad.2011.01.032

8. Baker H, Ryan TJ. Generalized pustular psoriasis. A clinical and epidemiological study of 104 cases. Br J Dermatol. 1968;80 (12):771-793. doi:10.1111/j.1365-2133.1968.tb11947.x

9. Navarini AA, Burden AD, Capon F, et al.; for ERASPEN Network. European consensus statement on phenotypes of pustular psoriasis. J Eur Acad Dermatol Venereol. 2017;31(11):1792-1799. doi:10.1111/ jdv. 14386

10. Hallopeau MH. Sur une asphyxie locale des extremities avec polydactylite suppurative chronique et poussées éphémères de dermatite pustuleuse disséminée et symétrique. Bull Soc Fr Dermatol Syph. 1890;1:39-45. French.

11. Mengesha YM, Bennett ML. Pustular skin disorders: diagnosis and treatment. Am J Clin Dermatol. 2002;3(6):389-400. doi:10.2165/ 00128071-200203060-00003
12. Benjegerdes KE, Hyde K, Kivelevitch D, Mansouri B. Pustular psoriasis: pathophysiology and current treatment perspectives. Psoriasis. 2016;6:131-144. doi:10.2147/PTT.S98954

13. Abbas O, Itani $\mathrm{S}$, Ghosn $\mathrm{S}$, et al. Acrodermatitis continua of Hallopeau is a clinical phenotype of DITRA: evidence that it is a variant of pustular psoriasis. Dermatology. 2013;226(1):28-31. doi: $10.1159 / 000346572$

14. Ranugha PS, Kumari R, Thappa DM. Acrodermatitis continua of hallopeau evolving into generalised pustular psoriasis. Indian J Dermatol. 2013;58(2):161. doi:10.4103/0019-5154.108096

15. Kim KH, Kim HL, Suh HY, et al. A case of acrodermatitis continua accompanying with osteolysis and atrophy of the distal phalanx that evoluted into generalized pustular psoriasis. Ann Dermatol. 2016;28 (6):794-795. doi:10.5021/ad.2016.28.6.794

16. Chen YL, Wang ZY, Ma L, Xu ZG. Three cases of IL36RN-associated pustulosis: an evolution of acrodermatitis continua of Hallopeau to generalized pustular psoriasis. Indian J Dermatol Venereol Leprol. 2020;86(5):562-565. doi:10.4103/ijdvl.JJDVL_581_19

17. Cusick MF, Libbey JE, Fujinami RS. Molecular mimicry as a mechanism of autoimmune disease. Clin Rev Allergy Immunol. 2012;42(1):102-111. doi:10.1007/s12016-011-8294-7

18. Yoneda K, Matsuoka-Shirahige Y, Demitsu T, Kubota Y. Pustular psoriasis precipitated by cytomegalovirus infection. $\mathrm{Br} J$ Dermatol. 2012;167(5):1186-1189. doi:10.1111/j.1365-2133.2012.11044.x

19. Ali FR, Green R, McMullen E, Motta L, Judge MR. Cutaneous cytomegalovirus complicating pustular psoriasis. $\mathrm{Br} J$ Dermatol. 2014;171(3):670-671. doi:10.1111/bjd.13026

20. Jiyad Z, Moriarty B, Creamer D, Higgins E. Generalized pustular psoriasis associated with Epstein-Barr virus. Clin Exp Dermatol. 2015;40(2):146-148. doi:10.1111/ced.12493

21. Sugiura K, Uchiyama R, Okuyama R, Akiyama M. Varicella zoster virus-associated generalized pustular psoriasis in a baby with heterozygous IL36RN mutation. $J$ Am Acad Dermatol. 2014;71(5):e216218. doi:10.1016/j.jaad.2014.07.015

22. Paniz Mondolfi AE, Hernandez Perez M, Blohm G, et al. Generalized pustular psoriasis triggered by Zika virus infection. Clin Exp Dermatol. 2018;43(2):171-174. doi:10.1111/ced.13294

23. Hewson CA, Jardine A, Edwards MR, Laza-Stanca V, Johnston SL. Toll-like receptor 3 is induced by and mediates antiviral activity against rhinovirus infection of human bronchial epithelial cells. J Virol. 2005;79 (19):12273-12279. doi:10.1128/JVI.79.19.12273-12279.2005

24. Sbidian E, Madrange M, Viguier M, et al. Respiratory virus infection triggers acute psoriasis flares across different clinical subtypes and genetic backgrounds. Br J Dermatol. 2019;181(6):1304-1306. doi:10.1111/bjd. 18203

25. Furue K, Yamamura K, Tsuji G, et al. Highlighting interleukin-36 signalling in plaque psoriasis and pustular psoriasis. Acta Derm Venereol. 2018;98(1):5-13. doi:10.2340/00015555-2808

26. Galván Casas C, Català A, Carretero Hernández G, et al. Classification of the cutaneous manifestations of COVID-19: a rapid prospective nationwide consensus study in Spain with 375 cases. Br J Dermatol. 2020;183(1):71-77. doi:10.1111/bjd.19163

27. Recalcati S. Cutaneous manifestations in COVID-19: a first perspective. J Eur Acad Dermatol Venereol. 2020;34(5):e212-e213. doi:10.1111/jdv.16387

28. Singh H, Kaur H, Singh K, Sen CK. Cutaneous manifestations of COVID-19: a systematic review. Adv Wound Care. 2021;10 (2):51-80. doi:10.1089/wound.2020.1309

29. Gisondi P, PIaserico S, Bordin C, Alaibac M, Girolomoni G, Naldi L. Cutaneous manifestations of SARS-CoV-2 infection: a clinical update. J Eur Acad Dermatol Venereol. 2020;34(11):2499-2504. doi:10.1111/jdv.16774

30. Kutlu Ö, Metin A. A case of exacerbation of psoriasis after oseltamivir and hydroxychloroquine in a patient with COVID-19: will cases of psoriasis increase after COVID-19 pandemic? Dermatol Ther. 2020;33(4):e13383. 
31. Sachdeva M, Mufti A, Maliyar K, Lytvyn Y, Yeung J. Hydroxychloroquine effects on psoriasis: a systematic review and a cautionary note for COVID-19 treatment. J Am Acad Dermatol. 2020;83(2):579-586. doi:10.1016/j.jaad.2020.05.074

32. Ozaras R, Berk A, Ucar DH, Duman H, Kaya F, Mutlu H. Covid-19 and exacerbation of psoriasis. Dermatol Ther. 2020;33(4):e13632. doi:10.1111/dth.13632

33. Nasiri S, Araghi F, Tabary M, Gheisari M, Mahboubi-Fooladi Z, Dadkhahfar S. A challenging case of psoriasis flare-up after COVID-19 infection. J Dermatolog Treat. 2020;31(5):448-449. doi:10.1080/09546634.2020.1764904

34. Gananandan K, Sacks B, Ewing I. Guttate psoriasis secondary to COVID-19. BMJ Case Rep. 2020;13(8):e237367. doi:10.1136/bcr2020-237367

35. Ghalamkarpour F, Pourani MR, Abdollahimajd F, Zargari O. A case of severe psoriatic erythroderma with COVID-19. J Dermatolog Treat. 2020;1-3. doi:10.1080/09546634.2020.1799918
36. Mathieu RJ, Cobb CBC, Telang GH, Firoz EF. New-onset pustular psoriasis in the setting of severe acute respiratory syndrome coronavirus 2 infection causing coronavirus disease 2019. JAAD Case Rep. 2020;6(12):1360-1362. doi:10.1016/j.jdcr.2020.10.013

37. Shakoei S, Ghanadan A, Hamzelou S. Pustular psoriasis exacerbated by COVID-19 in a patient with the history of psoriasis. Dermatol Ther. 2020;33(6):e14462. doi:10.1111/dth.14462

38. Dadras MS, Diab R, Ahadi M, Abdollahimajd F. Generalized pustular psoriasis following COVID-19. Dermatol Ther. 2020.

39. Sbidian E, Eftekahri P, Viguier M, et al. National survey of psoriasis flares after 2009 monovalent H1N1/seasonal vaccines. Dermatology. 2014;229(2):130-135. doi:10.1159/000362808

\section{Publish your work in this journal}

Biologics: Targets and Therapy is an international, peer-reviewed journal focusing on the patho-physiological rationale for and clinical application of Biologic agents in the management of autoimmune diseases, cancers or other pathologies where a molecular target can be identified. This journal is indexed on PubMed Central, CAS, EMBase,
Scopus and the Elsevier Bibliographic databases. The manuscript management system is completely online and includes a very quick and fair peer-review system, which is all easy to use. Visit http://www.dovepress.com/testimonials.php to read real quotes from published authors. 